\title{
The draft genome of Labeo catla
}

\author{
Lakshman Sahoo, Paramananda Das* (1), Bismay Sahoo, Gargee Das, Prem Kumar Meher, Uday Kumar Udit, \\ Kanta Das Mahapatra and Jitendra Kumar Sundaray
}

\begin{abstract}
Objective: Labeo catla (catla), one of the three Indian major carps, is native to the Indo-Gangetic riverine system of India as well as the rivers of Pakistan, Bangladesh, Nepal and Myanmar. Its higher growth rate and compatibility with other major carps, specific surface feeding habit, and consumer preference have increased its popularity in carp polyculture systems among the fish farmers in Indian subcontinent. Recent advancement in sequencing technology coupled with massive parallel sequencing platforms has facilitated accelerated genetic improvement in aquaculture species through integration of genomics tools. A draft genome and allied resources are lacking in catla. Therefore, in the present study, we have performed de-novo assembly of Labeo catla for the first time.

Data description: A male farm reared catla was used for extracting high molecular weight genomic DNA followed by sequencing in Oxford Nanopore and Illumina platforms. Approximately, $80 \times$ coverage of sequence data was assembled adopting the hybrid assembly strategy. The assembled genome size of catla was $1.01 \mathrm{~Gb}$ containing 5345 scaffolds with N50 value $0.7 \mathrm{Mb}$ and more than $92 \%$ BUSCO completeness. Gene annotation resulted in 25,812 predicted genes.
\end{abstract}

Keywords: Labeo catla, Hybrid assembly, Genomics resource, Indian major carp

\section{Objective}

Aquaculture is the rapidly emerging food production sector all over the world and it is going to be the primary source of fish and shellfish for human diet in the coming future [1]. Genetic improvement of performance traits has huge potential to meet the increasing demand of quality animal protein in the event of exponential growth of human population. Well-designed breeding programmes integrated with genomics tools can accelerate the production and productivity. Recent advancement in sequencing technology coupled with massive parallel sequencing platforms has paved the way for expediting genetic improvement programs in aquaculture species.

Labeo catla (catla), one of the Indian major carps, is native to the Indo-Gangetic riverine system of India as well as the rivers of Pakistan, Bangladesh, Nepal and

*Correspondence: pdas77@hotmail.com

Fish Genetics and Biotechnology Division, ICAR-Central Institute

of Freshwater Aquaculture, Bhubaneswar, Odisha 751002, India
Myanmar. Its higher growth rate and compatibility with other major carps, specific surface feeding habit, and consumer preference have increased its popularity in carp polyculture systems among the fish farmers in India, Bangladesh, Myanmar, Laos, Pakistan and Thailand [2]. L. catla currently accounts for $\sim 3.4 \%$ of total freshwater aquaculture production worldwide [3]. With an aim to generate consolidated genomics resource for supporting genetic improvement, we have undertaken de-novo assembly of catla for the first time. The draft genome will also be an important resource for comparative genomics, biological and evolutionary studies of cyprinid species.

\section{Data description}

One farm-reared mature (2 years old) male catla weighing approximately $1.7 \mathrm{~kg}$ was collected from ICAR-Central Institute of Freshwater Aquaculture (CIFA) farm for this study. Before tissue sampling, fish was anesthetized with MS-222 (300 mg/l) and then weighed. High molecular weight genomic DNA was isolated from testis tissue using standard phenol-chloroform method [4]. The

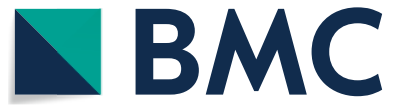

(c) The Author(s) 2020. This article is licensed under a Creative Commons Attribution 4.0 International License, which permits use, sharing, adaptation, distribution and reproduction in any medium or format, as long as you give appropriate credit to the original author(s) and the source, provide a link to the Creative Commons licence, and indicate if changes were made. The images or other third party material in this article are included in the article's Creative Commons licence, unless indicated otherwise in a credit line to the material. If material is not included in the article's Creative Commons licence and your intended use is not permitted by statutory regulation or exceeds the permitted use, you will need to obtain permission directly from the copyright holder. To view a copy of this licence, visit http://creativeco mmons.org/licenses/by/4.0/. The Creative Commons Public Domain Dedication waiver (http://creativecommons.org/publicdomain/ zero/1.0/) applies to the data made available in this article, unless otherwise stated in a credit line to the data. 
Table 1 Overview of data files/data sets

\begin{tabular}{llll}
\hline Label & Name of data file/data set & $\begin{array}{l}\text { File types (file } \\
\text { extension) }\end{array}$ & Data repository and Identifier (Dol or Accession number) \\
\hline Data file 1 & Sequence data & Table 1.docx & https://doi.org/10.6084/m9.figshare.12271589 [5] \\
Data file 2 & Assembly statistics & Table 2.docx & https://doi.org/10.6084/m9.figshare.12271619 [10] \\
Data file 3 & Assembly data & FASTA & https://wWw.ncbi.nlm.nih.gov/assembly/GCA_012976165.1 [11] \\
Data file 4 & Whole genome sequence data & FASTA & NCBI GenBank (Accession numbers VONZ01000001- \\
& & & VONZ01005345) https://identifiers.org/ncbi/insdc:VONZ0 \\
& & & 0000000 [19] \\
\hline
\end{tabular}

qualitative and quantitative assessment of DNA were performed by NanoDrop spectrophotometer (Thermo Fisher Scientific, Wilmington, DE, U.S.A.) and Qubit fluorometer (Invitrogen, Carlsbad, CA, USA) followed by checking on $0.8 \%$ agarose gel. Genomic DNA was sheared using a Covaris S2 sonicator (Covaris, Woburn, Massachusetts, USA) to generate fragments in the range of $200 \mathrm{bp}$ to $20 \mathrm{~kb}$. Four Paired end libraries (insert size: $350 \mathrm{bp}$ ) for Illumina Nextseq500 platform and one library (mixed insert size) for Oxford Nanopore were prepared and sequenced as per manufacturer's instruction. A total of $80.28 \mathrm{~Gb}$ sequence data (Table 1, Data file 1) [5] were generated after quality check by FastQC tool [6]. The de novo hybrid assembly was performed with default parameters using MaSuRCA 3.2.8 [7] followed by scaffolding and Gap closing with SSPACE v3.0 [8] and GapCloser v1.12b [9], respectively. This yielded 5,345 scaffolds with N50 value of $0.7 \mathrm{Mb}$ (Table 1, Data file 2) [10] and largest fragment of $6.8 \mathrm{Mb}$. The assembled genome size of catla is $1.01 \mathrm{~Gb}$ (Table 1, Data file 3) [11] against an in silico estimated genome size of $0.95 \mathrm{~Gb}$. The evaluation of genome by Benchmarking Universal Single-Copy Orthologs (BUSCO) version 3.0 [12] and using Actinopterygii odb9 core gene set revealed 92\% complete, $87.9 \%$ complete and single copy, $4.1 \%$ complete and duplicated, $4.1 \%$ fragmented and $4.05 \%$ missing BUSCOs. RepeatModeler [13] was used for de novo repeat modelling which showed $47.58 \%$ of repeat content in catla genome. The genome wide simple sequence repeats of assembled catla genome was 391,331 .

The catla genome is predicted to contain 25,812 protein-coding genes. Additionally, scaffold_2219 of a size of $16,600 \mathrm{bp}$, was found to be of mitochondrial origin, with 13 mRNAs, 22 tRNAs and 2 rRNAs. Functional annotation of the final set of predicted protein sequences was carried out by BLAST2GO v5.0. Out of 25,812 genes, 17,500 were found to have GO term assigned to them. The number of protein coding genes identified in catla $(25,812)$ is comparable to the genomes of sequenced diploid cyprinids such as Labeo rohita [14], Ctenopharyngodon idellus [15], Danio rerio [16] and Anabarilius grahami [17]. Orthologous relationship among these species using OrthoVenn [18] showed a total of 8,494 orthologous gene clusters to be shared by all five species, with 1,357 species specific gene clusters. The whole genome sequence data has been deposited in the GenBank (Table 1, Data file 4) [19

\section{Limitations}

The assembled genome size of Labeo catla is $1.01 \mathrm{~Gb}$ constituting 5345 scaffolds. The number of unassembled regions is 649 and the number of bases positioned in this gap is $0.8 \mathrm{Mb}$.

\section{Abbreviations}

FAO: Food and Agriculture Organisation of the United Nations; Gb: Giga base pair; MaSuRCA: Maryland Super-Read Celera Assembler; BUSCO: Benchmarking Universal Single-copy Orthologs; GO: Gene ontology; Mb: Mega base pair.

\section{Acknowledgements}

We acknowledge the financial support by the Department of Biotechnology, Govt. of India, New Delhi under Centre of Excellence program. Authors are thankful to the Director, ICAR-CIFA, Bhubaneswar for providing the facilities to work under the project. We thank Dr. P. C. Das, ICAR-CIFA, Bhubaneswar for providing the farm reared catla sample.

\section{Authors' contributions}

PD, JKS, KDM and PKM conceptualised and designed the project. PD and LS designed the experiments. BS, GD, LS, PD and UKU performed sample collection, tissue extraction and DNA isolation. LS, BS and GD performed data analysis. PD, LS and BS and GD wrote and reviewed the manuscript. All the authors read and approved the manuscript.

\section{Funding}

This work was supported by the Department of Biotechnology, Govt. of India under the Grant No. BT/AAQ/3/SP13797/2017.

\section{Availability of data and materials}

This Whole Genome project has been deposited at DDBJ/ENA/GenBank under the Bioproject id: PRJNA557138 and Acc no: VONZ00000000 (https://ident ifiers.org/ncbi/insdc:VONZO0000000) [19]. The version described in this paper is version VONZ01000000. Please see Table 1 and references $[5,10,11,19]$ for details and links to the data.

\section{Ethics approval and consent to participate}

All handling of fish was carried out following the guidelines for control and supervision of experiments on animals by the Government of India and approved by Institutional Animal Ethics Committee (AEC) of ICAR-CIFA. 


\section{Consent for publication \\ Not applicable.}

\section{Competing interests}

The authors declare that they have no competing interests.

Received: 15 May 2020 Accepted: 19 August 2020

Published online: 03 September 2020

\section{References}

1. Anderson JL, Asche F, Garlock T, Chu J. Aquaculture: its role in the future of food. World Agricultural Resources and Food Security. Emerald: Bingley; 2017. p. 159-173.

2. FAO. Fisheries and aquaculture topics. Rome: FAO Fisheries and Aquaculture Department; 2006-2020.

3. FAO. FAO Yearbook of Fishery and Aquaculture Statistics 2017. Rome: FAO; 2019.

4. Sambrook J, Russel DW. Molecular cloning: a laboratory manual. Cold Spring Harbor: CSH Laboratory Press; 2001

5. Das P. Table1. docx. Figshare; 2020. https://doi.org/10.6084/m9.figsh are.12271589.

6. FASTQC program. https://www.bioinformatics.babraham.ac.uk/projects/ fastqc/. Accessed 12 Dec 2018.

7. Zimin AV, Marçais G, Puiu D, Roberts M, Salzberg SL, Yorke JA. The MaSuRCA genome assembler. Bioinformatics. 2013;29:2669-777.

8. Boetzer M, Henkel CV, Jansen HJ, Butler D, Pirovano W. Scaffolding preassembled contigs using SSPACE. Bioinformatics. 2010;27:578-9.

9. Luo R, Liu B, Xie Y, Li Z, Huang W, Yuan J, et al. SOAPdenovo2: an empirically improved memory-efficient short-read de novo assembler. GigaScience. 2012;1:18

10. Das P. Table 2.docx. Figshare; 2020. https://doi.org/10.6084/m9.figsh are.12271619.
11. Sahoo L, Das G, Mahapatra KD, Sahoo B, Meher PK, Udit UK et al. CIFA_ Catla 1.0. NCBI Assembly; 2020. https://www.ncbi.nlm.nih.gov/assembly/ GCA_012976165.1.

12. Simão FA, Waterhouse RM, loannidis PP, Kriventseva EV, Zdobnov EM. BUSCO: assessing genome assembly and annotation completeness with single-copy orthologs. Bioinformatics. 2015;31(19):3210-2.

13. RepeatModeller program. https://www.repeatmasker.org/RepeatMode ler.html. Accessed 03 June 2019.

14. Das P, Sahoo L, Das SP, Bit A, Joshi CG, Kushwaha B, et al. De novo assembly and genome-wide SNP discovery in rohu carp Labeo rohita. Front Genet. 2020;11:386

15. Wang Y, Lu Y, Zhang Y, Ning Z, Li Y, Zhao Q, et al. The draft genome of the grass carp (Ctenopharyngodon idellus) provides insights into its evolution and vegetarian adaptation. Nat Genet. 2015;47(6):625-31.

16. Howe K, Clark MD, Torroja CF, Torrance J, Berthelot C, Muffato M, et al. The zebrafish reference genome sequence and its relationship to the human genome. Nature. 2013;496:498-503.

17. Jiang W, Qiu Y, Pan X, Zhang Y, Wang X, LvY, et al. Genome assembly for a Yunnan-Guizhou Plateau "3E" fish, Anabarilius grahami (Regan), and its evolutionary and genetic applications. Front Genet. 2018:9:614.

18. Wang Y, Coleman-Derr D, Chen G, Gu YQ. OrthoVenn: a web server for genome wide comparison and annotation of orthologous clusters across multiple species. Nucleic Acids Res. 2015;43(W1):W78-W84.

19. Sahoo L, Das G, Mahapatra KD, Sahoo B, Meher PK, Udit UK, et al. Labeo catla isolate CC01, whole genome shotgun sequencing project. GenBank. https://identifiers.org/ncbi/insdc:VONZ00000000; 2020

\section{Publisher's Note}

Springer Nature remains neutral with regard to jurisdictional claims in published maps and institutional affiliations.
Ready to submit your research? Choose BMC and benefit from:

- fast, convenient online submission

- thorough peer review by experienced researchers in your field

- rapid publication on acceptance

- support for research data, including large and complex data types

- gold Open Access which fosters wider collaboration and increased citations

- maximum visibility for your research: over $100 \mathrm{M}$ website views per year

At BMC, research is always in progress.

Learn more biomedcentral.com/submissions 